\title{
数量経済研究会報告
}

The meeting of econometrics studies

\section{Studies on Interregional Migration in the Former Soviet Union and Russia : A Survey}

\author{
Kazuhiro Kumo \\ Graduate School of Economics, Kyoto University
}

\section{Introduction}

In the field of the regional science, population migration has long been one of the main subjects. There are many studies on migration in developing countries and the United States. On the other hand, only a few students investigated population migration in the former Soviet Union or Russia until the 1960s. As Lewis pointed out, it is surprising that the problem of optimum population location did not attract academic attention in the planned economy (1). After that, however, exploitation in the Far North regions used to be accompanied by population outflows (2). Thus Russian scholars also began to study population migration. This paper surveys studies on migration in the former Soviet Union and in Russia after Lewis's, which is the only survey in English.

\section{Factors of Migration in the Earlier Period :}

The War, Dictatorship and Regional Development Policies

Policy-induced population redistribution had significant effects on geographical patterns of Soviet population before World War II, especially in Siberia and the Far North regions (3).

According to Perevedentsev (in Russian), in the Far North regions there were many cities whose population in 1963 was 100 times what it was in 1927 (4). Although he contended that this population growth in northern regions was attributed to development policies and to economic incentives as high wages, the induced population redistribution also must have had great effects on migration patterns (in these days Soviet scholars could not discuss the dictatorship).

Marian'ski, Pod'yachikh (both in Russian) and others discussed population redistribution relative to World War II(5). In order to shield plants and the work force 
from the German army, more than 10 million people were forced to move eastward during the wartime. Of course, as they mentioned, population losses during World War II also played a critical role.

In the early Soviet era, regional development policies of the Soviet government aimed at diminishing regional disparity. Sagers et al. analyzed industrial dispersion across the Union republics through the use of entropy measures (6). They proved that inequality among republics decreased between 1926 and 1960. Per capita federal investment in less advanced areas was very large until the 1960 s and there were large population inflows into such regions as the Far East and Siberia (7). Thus it was said that population migration in the Soviet Union was planned and organized by the central government (8). These may be the reasons why migration in Russia had received scant attention.

\section{Economic Incentives Given by the Government:}

Its Effect on Migration Patterns

After the 1950 s, the government prompted people to move toward the frontier through offering high wages and providing jobs to newly graduated university students. Samorodov and others. mentioned that these were main policies of the Soviet Union government to fill the regional labor demand gap (9) and they contended that development policies of the Soviet government worked well until the 1960s (10). In Central Asia, the less advanced area, per capita federal investment was very large and massive population inflows could be observed there in those days (11). Population decreased in advanced regions like Russia due to outmigration. These may indicate the effectiveness of development policies implemented by the Soviet government.

However, as Khodachekh pointed out, the Far North regions stood out in terms of population mobility. Living conditions in these regions did not fully satisfy the migrants (12).

During the 1960 s political incentives began to lose their effect on population migration (13), and the region-specific factor, that is, quality of life became a significant factor of migration. In the Soviet Union as well as in decentralized countries various factors as income, the race, the climate, housing conditions, transportation conditions and so on simultaneously had effects on migration decision (14).

In addition, the productivity of capital apparently decreased. By estimating the marginal productivity of labor and capital, Dienes showed that investment in Siberia and Kazakhstan was inefficient during the 1960 s when economic efficiency was not the prime objective of the Soviet government (15). However, in spite of the government's policies, due to the high cost of laborers resetting in developing areas population outflows continued. According to Dienes, these facts in turnled the government to change investment policies.

Calculated from databooks (Narodnoe Khozyaistuo), per capita federal investment in 
the Central Asia decreased yearly during the 1970s whereas investment in the Russian Federation gradually increased.

\section{The Turning point of Migration Patterns in the Soviet Union :}

Changes in Development Policies, Limitation of Economic Incentives and Migration

Migration patterns in the USSR changed drastically in the mid-1970s. Although Ball and others also referred to this change in migration patterns in the Soviet Union, all these studies were based on Census data, therefore their results were biased by more than ten years (16).

For clarification, we give two figures. One shows annual data on Union republic net migration rates, and another shows cross-section correlation coefficients between interUnion republic net migration rates and various factors such as per capita federal investment in the respective republic, per capita number of doctors and so on. See Figure 1 and 2.

From these figures we can observe that people flowed into the Central Asian republics during the first half of the 1970s, and at the same time there were population outflows from Russia (note : all Slavic republics lost their population throughout the 1960s. See 17.). However, in the latter half of the 1970 s their positions were reversed. Correlation coefficients between migration and per capita government investment etc. were very low in the first half of the 1970s, but these extremely increased in the latter half of the period (Figure 2).

This phenomenon can be interpreted in the following manner : By the first half of the 1970s, political incentives had already lost their effects on migration. However, the Soviet government continued to invest in the less developed areas. Thus the correlation between migration and these economic factors was very weak. But in the latter half of the period, the government changed its development policy and started to invest in the advanced areas like Russia. As a result, migrants and capital flowed into the same places. This further suggests that the policy itself was affected by population flows, not vice versa.

Mitchneck was the first to analyze population migration in the USSR from the viewpoint of regional science (18). He employed gravity and spatial interaction models and showed that compared to distance, investment affected migration decision more significantly. His analysis indicates the effect of central planning on population redistribution. It should be noted, however, that not only inflows but also large outflows from in the Far East and Siberia were observed in the 1970s. In addition, he also found that investment was a very weak pull factor of migration in the Far East. Here, we can see the limitations of political incentives. An increase in manufacturing employment also did not serve as a strong enough pull factor for interregional migration. In this regard, he offered an 
Figure 1. Net migration rates of Union republics, 1972-1986.

a : Slavic republics

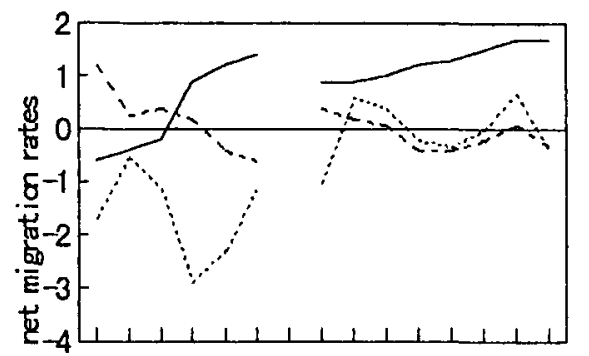

$197219741976 \quad 1980198219841986$ 1973197519771979198119831995

\begin{tabular}{l} 
- Russia -...Belarus \\
-.ukraine \\
\hline
\end{tabular} b : the Central Asia

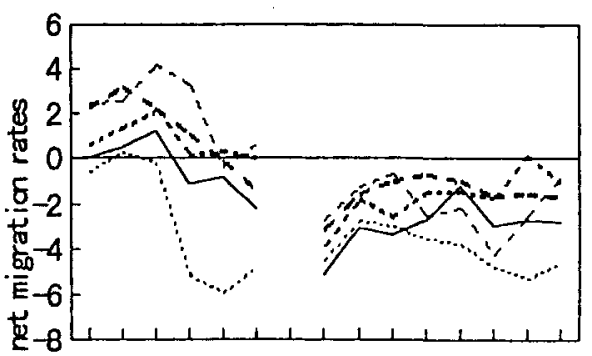

197219741976 . 1980198219841986

1973197519771979198119831985

$\begin{array}{ll}\text { - Uzbekistan } & \text {--Turkmenistan } \\ \text {-.. Kazakhstan } & \text {-. Tadzhikstan } \\ \text { - Kyrgyzstan } & \end{array}$

(source : Narodnoe Khozyaistvo, TsSU SSSR, annual databooks)

Figure 2. Correlation Coefficients between Migration Rates and Various Factors

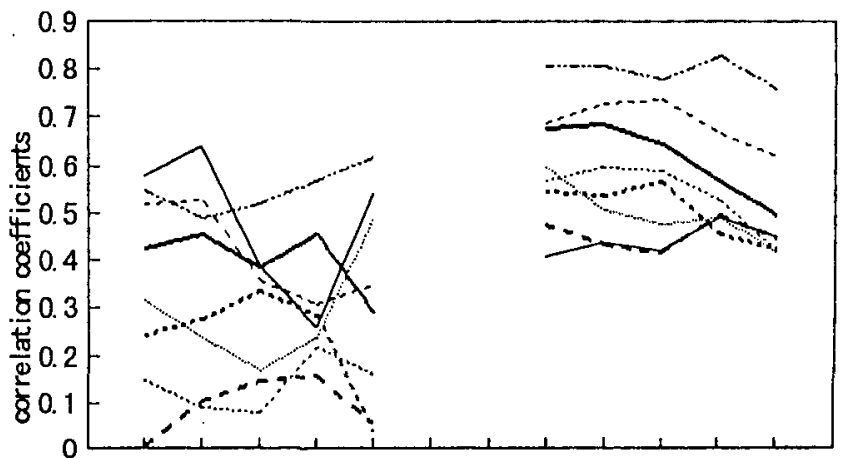

19711972197319741975197619771978197919801981198219831984

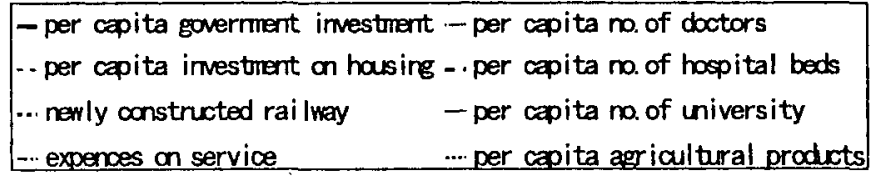

(source : Narodnoe Khozyaistvo, TsSU SSSR, annual databooks) 
interesting explanation, that is, "the economic policy of full employment also decreases the influence of regional employment changes as a push or pull factor".

As Romanenkova and others pointed out, urbanization similar to the West also occurred in Russia in spite of the restriction placed against in-migration into large cities (19). Attempts at reconstruction to create large economic complexes in rural areas in order to evade the rural depopulation had little effects on migration patterns.

Allowing free migration to some degree, the central government had to give various incentives in order to attain the optimum population distribution as the result of free population flows. To realize this, the government must estimate each individual's utility function. However, due to the complexity of calculations involved, it is rather impossible to calculate the optimum population distribution. "Population redistribution based on central planning" may, after all, not be completed even in the planned economy. Just as regional development policies in Japan did not necessarily work well, development policies in general is often troubled with uncertainty in attaining the original plan. It seems that the Soviet central planning was not so different from the development policy in the Third World in securing regional labor supply.

All these indicates that even in the planned economy, political incentives could not work perfectly. However, the development policy worked to a certain extent, as could be seen from in-migration into Siberia and the Far East during the 1980s (20).

\section{Recent Migration Trends in Russia: Some Striking Characteristics after the Collapse of the Soviet Union}

The Soviet Union broke up in 1991 and after that marketization commenced. This phenomenon must have exerted an influence on migration patterns. Deteriaration of living conditions, regionalism, racial strives and so on became pronounced (21). Regional differential in housing conditions, employment conditions, the climate and the distance variables also became more significant because the subsidy by the central government was cut off after $1992(22)$.

Kumo examines changes in interregional migration patterns in Russia due to the transformation of the economic system mainly by differentiating political incentive variables which the government can easily regulate, and region-specific factors which hardly change in a short term (23). The correlation coefficients between migration rates and political incentives (federal investment and wages) were positive during the Soviet era and became negative after 1992. This result manifests the effectiveness of political incentives given by the central government. However, the regional development policies implemented in the Soviet era may not have been socially efficient in causing migration inflows and excess labor supply in the Far North regions. The regression coefficient of the dummy variable for climate, the absolute value of which is very high after 1992 , 
suggests large population outflows from the Far North regions. This may indicate the existence of excess labor supply in the Far North regions induced by the government during the Soviet period.

\section{Concluding Remarks}

Mitchneck and Cole et al. proved that distance and economic variables played an important role in migration decision in the Soviet Union. Kumo showed the importance of considering quality of life in analyzing migration in Russia. The factors of migration decision in Russia seem to be similar to those in developing countries. As Mitchneck pointed out, it can be said that "the statistically significant economic variables indicate the appropriateness of using Western theories to analyze migration in the Soviet context". Of course, however, we can not assert the validity of his statement yet because the definition of each variable in the analysis above is somewhat different from that of traditional migration studies.

There was no annual data on interregional population migration in the USSR during the Soviet era. The available ones are Norodnoe Khozyaistvo, but these include only inter-union republic net migration data. Although census data contain population inand outflow tables fot 27 regions, the census itself was conducted irregularly, therefore the analysis was biased by the time interval descrepancy. However, such a situation has been improved especially in recent years. Many databooks are published (24, Kumo used these data in his analysis) and the terminology is gradually adjusted to the Western definition. More detailed investigation will be feasible in the near future.

Acknowledgment :

I am indebted to Prof. Takatoshi Tabuchi (Univ. of Tokyo). Prof. Sadayoshi Ohtsu (Kobe Univ.) and my colleague Maria Makabenta for their valuable comments and suggestions.

\section{English literature :}

(1)Lewis,R.,A. "The Postwar Study of Internal Migration in the USSR", Soviet Geography (SG), vol.10.No.4, 1969. pp.157-166.

(2)Pereverdentsev,V., "Contemporaly Migration in the USSR", SG. vol.10. No.4, 1969, pp.192-208. Zayonchkovskaya.Zh.A., Zakharina.D.M., "Problems of Providing Siberia with Manpower”, SG. vol.13, No.10, 1972. pp.671-683.

Souza.P., "The Nature of the Manpower Problem in the Development of Siberia", SG. vol.27. No.10, 1986. pp.689-715.

(3)Newth,J., "The 1970 Soviet Census". Soviet Studies (SS), No.2. 1972, pp.201-222.

(5)Newth,J., "The Soviet Population : War Time Losses and the Postwar Recovery", SS, vol.15, No.3, 1964, pp.345-351.

(6)Sagers, M. et al., "Industrial Dispersion in the Soviet Union : An Application of Entropy Measures", SG, vol.20, No.10, 1979, pp.567-586. 
(7)Pokshishevskiy.V. et al., "On Basic Migration Patterns”, SG. No.10.1964, pp.3-18.

(8)Vorobyev.V.V., Kozhukhovskaya, N. F., "Population Movements in the South of Krasnoyarsky Kray", SG, vol.14. No.9, 1973, pp.551-563.

Rodgers,A., "The Location Dynamics of Soviet Industry", Annals of the Association of American Geographers, vol.64, No.2, 1974, pp.226-240.

(9)Samorodov,A., "Labor Market Problems and Developments in the Republics", The New Soviet Labor Market (NSLM), ed. Standing,G., Geneva. International Labor Office, 1991. pp.145163.

(11)Lukhmanov,D.N., "Changes in the Distribution of Rural Settlement in Northern Kazakhstan from 1959 to $1963 ", S G$, vol.9, No.8, 1968, pp.699-710.

(12)Khodachek.V.M., "On the Formation of Population in Regions of the Far North of USSR", SG, vol.15, No.5. 1974, pp.288-298.

(14)Perevedentsev,V.I., "The Influence of Ethnic Factors on the Territorial Redistribution of Population", SG, vol.6, No.8. 1965, pp.40-50.

Alekseyev, A.I., et al., "Urban-Rural Migration in the Non-Chernozem Zone of the RSFSR", SG, vol.21, No.5, 1980, pp.301-307.

Nechemias.C., "Regional Differentiation of Living Standards in the RSFSR", SS, No.3, 1980. pp.366-378.

Powell,D.E., "The Rural Exodus", The Soviet Economy-Continuity and Change, ed. Bornstein,

M.,Colorado, Westview Press, 1981, pp.149-163.

(15)Dienes.I. "Investment Priorities in the Soviet Regions". Annals of the Association of American Geograr. ers, vol.62,No.3, 1972, pp.437-454.

(16)Ball,B., Demko,G.J., "Internal Migration in the Soviet Union", Economic Geography, vol.54, No.2, 1978, pp.95-114.

Rowland,R.H., "Regional Migration and Ethnic Russian Population Change in the USSR (1959 79)”. SG, vol.23, No.8, 1982, pp.557-583.

(18)Mitchneck.B.A., "Geographical and Economic Determinants of Interregional Migration in the USSR, 1968-1985". SG, vol.32, No.3, 1991, pp.168-189.

(19)Romanenkova, G.. "Rural -Urban Labor Migration in the USSR : Its role in Redistributing Population and Labor Resources", NSLM, 1991, pp.165-175.

Harris.C.D., "Urbanization and Population Growth in the Soviet Union, 1959-1970", The Geographical Review, vol.61, No.1, 1971, pp.102-124.

Lydolph.P.E.. "Recent Population Characteristics and Growth in the USSR", SG, vol.30, No.10. 1989, pp.711-729.

Cole,J.P., "Changes in the Population of Larger Cities of the USSR", SG, vol. 31, No.3,1990, pp.160-172.

(20)Rowland,R.H.. "National and Regional Population Trends in the USSR, 1979-89 : Preliminary Results from the 1989 census", SG, vol.30, No.9,1989, pp.635-669.

Sallnow,J., "The Soviet Far East : A Report on Urban and Rural Settlement and Population Change, 1969-1989", SG, vol.30, No.9, 1989, pp.670-683.

(22)Cole,J.P., Filatotchev.I.V., "Some Observations on Migration within and from the Former USSR in the 1990", Post SG (PSG), vol.33, No.7, 1992, pp.432-453.

Bond,A.R., "Outmigration, Economic Dislocation, and Reassessment of the Resource in the Russian Far North", PSG, vol.35, No.5, 1994, pp.299-305.

(23)Kumo,K.."Economic System Conversion and Migration Transition in Russia". Review of Urban and Regional Development Studies, vol.9, No.1, 1997. 
Russian literature :

(2)Топилин,А, „Основные Направления Межреспубликанской Миграции Населения”, Плановое Хозяйство, ㅇ..1, 1988, pp.86-91.

(3)Брук,С., Население Земного Шара, Москва, Наука,1965.

(4)Переведенцев,В, Миграчия Населепия и Трудовые Проблемы Сибири, Новосибирск, Наука ,1966.

(5)Марианьский,А, Современные Мирачии Населения, Москва, Статистика, 1969 (Перевод с Польского).

Подьячих,П, Население СССР, Москва, Политическая Литература, 1961.

Рябушкин, T. et al., „Динамика и Структура Насления CCСР за 60 лнт”, Bопросы Экономики (ВЭ), No.9, 1982, pp.10-19.

(6)Переведенцев,В, „Bonросы Териториального Перераспределения Трудовых Ресурсов”, $B$ Э , No.5, 1962, pp.48-56.

Денисова,Л. et al., „Некоторые Данные о Миграции Населения в”, Вестник Сактистики (BC), No.7, 1965, pp.16-21.

(7)Иванова,Р., „О Развитии Восточных Районов и Обеспечении их Рабочей Силой”, ВЭ, No.1, 1973, pp.40-48.

(9)Куприенко,Л., „Влияние Уровня Жизни на Движение Трудовых Ресурсов”, ВЭ, №.3, 1972, pp.22-31.

(10)Милованов,Е, „Проблемы Освоения Дальнего Востока”, Экономическая Жизии Дальнего Востока (3) (ЭЖДВ), No.1, 1994, pp.37-41.

(11)Караваев,В., „Региональная Инвестиционная Политика : Российские Проблемы и Международный Опыт”, ВЭ, No.3, 1995, pp.135-143.

(13)Воробьев, В,В., Население Восточной Сибири, Новосибирск., Наука, 1977.

(14)Капустин,К., Кузнецова,Н., „Региональные Особенности Повышения Жизненног Уровня Населения", Экономическая Наука, №.1, 1972, pp.49-58.

Зинченко,И., „Национальный Состав Населения СССР”, ВC, o.6, 1982, 3зю23-29.

(17)Переведенцев,В, „Рынок Труда и Миграции Населения СССР”, ВЭ, No.9, 1991, pp.45-54.

(19)Рыбаковский, Л., Население СССР за 70 лет, Москва, Наука, 1988.

(20)Моисеенко,В, „Влияние Миграции на Формирование Населения”, BЭ,No.7,1983, pp.8-14.

(21)Можина,М., „Анализ Дифференциации Доходов Населения”, Экономист (Э), No.1, 1995, pp.33-42.

Красинец, E. et al., „Демографическая Ситуация в России”, Э, №.2, 1993, pp.35-43.

Макаорова,М.,Беденков,А., „Социально-Экономическое Положение Регионов России”, BЭ, No.3, 1995, pp.121-128.

Попов,А, „Движение Численности Населения и Трудовых ресурсов Северо-Востока Районы”, Э, No.4, 1995, pp.78-84.

(22)Ивлевин,Я., „Социально-Экономические Проблемы Воспроизводства Населения и Трудовых Ресурсов Дальнего Востока и Забайкалья”, ЭЖДВ(2), No.1,1993, pp.196-198.

Красинец, Е. et al., „Особенности Миграционных Процессов в России”,Э,No.2,1994, pp. 79-85.

Виленский,А. et al., „Экономическая Реформа и Положение Регионов”, Э, No.3, 1993, pp.3-14.

(24)Госкомстат РФ, Показатели Экономического Развития Республик, Краев, Областей РФ, Москва, 1992. 
- Численность, Состав и Движсение Населения в РФ, Москва, 1992.

- Показтели Сочиального Развития РФ и её Регионов, Москва, 1993.

- основнье Показатели Уровия Жизни Населения РФ в 1993, Москва,1994.

- Численность и Миграция паселения РФв 1994, Москва, 1995.

- $\quad$ Естественное Движение Населения РФ за 1994, Москва, 1995.

- Демографический Еэсегодıик России, Москва (annually, since 1991).

- Российский Статистический Ежсегодник, Москва (annually, since 1995). 